\title{
ФОРМУВАННЯ ПРОФЕСІЙНИХ КОМПЕТЕНТНОСТЕЙ МАЙБУТНІХ УЧИТЕЛІВ ФІЗИЧНОЇ КУЛЬТУРИ ЯК ЗАПОРУКА УСПІШНОЇ ПЕДАГОГІЧНОЇ ДІЯЛЬНОСТІ
}

\author{
Стасенко О. А. \\ кандидат педагогічних наук, дочент, \\ дочент кафедри теорії і методики фізичного виховання \\ Центральноукраӥнський державний педагогічний університет імені Володимира Винниченка \\ вул. Шевченка, 1, Кропивницький, Украӥна \\ orcid.org/0000-0001-6112-4363 \\ oleksii.stasenko@gmail.com
}

\author{
Ключові слова: професійна \\ компетентність, знання, \\ уміння, майбутні учителі \\ фізичної культури, освітній \\ проиес.
}

\begin{abstract}
У статті наголошується на тому, що вдосконалення державних стандартів в освітній галузі є одним із ключових напрямів реформування системи підготовки майбутніх учителів фізичної культури, оскільки педагогічна діяльність фахівця, який формує особистість дитини, певною мірою складна. Визначено, що підготовка студента як майбутнього вчителя фізичної культури неможлива без усвідомлення себе як суб'єкта педагогічної діяльності, яка повинна включати як набуття спеціальних знань, умінь та навичок, так і формування професійних компетентностей відповідно до вимог сучасних закладів середньої освіти. Узагальнено досвід фахової підготовки майбутніх учителів фізичної культури, який набувається у процесі вивчення психолого-педагогічних, медикобіологічних та спеціальних дисциплін. Установлено, що одним із першочергових завдань фахової підготовки майбутніх учителів фізичної культури, які постають перед сучасною системою вищої педагогічної освіти, $є$ ефективний пошук та використання оптимальних шляхів підвищення ефективності навчальних технологій, спрямованих на формування професійних компетентностей майбутніх педагогів. Доведено, що формуванню професійної компетентності у закладах вищої освіти педагогічного профілю має приділятися велика увага. Майбутні учителі фізичної культури повинні вміти різноаспектно вирішувати комплексні завдання і проблеми в галузі фізичної культури, керуючись принципами толерантної комунікації, творчої й інноваційної професійної діяльності у виробничих ситуаціях, що характеризуються невизначеністю умов та вимог сьогодення. Обгрунтовано структуру особистості вчителя фізичної культури, в якій знаходять своє відображення загальні та фахові (предметні) компетенції, а також програмні результати навчання (знання), уміння й комунікація. Акцентується увага на оволодінні системою практичних умінь та навичок займатися головними видами $\mathrm{i}$ формами раціональної фізкультурної діяльності в закладах середньої освіти; збереженні й зміцненні здоров'я, розвитку і вдосконаленні психофізичних можливостей, якостей та властивостей особистості; набутті досвіду творчого використання фізкультурно-оздоровчої та спортивно-масової діяльності для досягнення особистих і професійних цілей; формуванні загальної культури, гуманістичної спрямованості, компетентності, педагогічних здібностей та педагогічної техніки; умінні спілкуватися з колегами, учнями та їхніми батьками.
\end{abstract}




\title{
FORMATION OF PROFESSIONAL COMPETENCIES OF FUTURE PHYSICAL EDUCATION TEACHERSAS A GUARANTEE OF SUCCESSFUL PEDAGOGICAL ACTIVITY
}

\author{
Stasenko O. A. \\ Candidate of Pedagogical Science, Associate Professor, \\ Associate Professor at the Department of Theories and Methods of Physical Education \\ Volodymyr Vynnychenko Central Ukrainian State Pedagogical University \\ Shevchenka str., 1, Kropyvnytskyi, Ukraine \\ orcid.org/0000-0001-6112-4363 \\ oleksii.stasenko@gmail.com
}

Key words: professional competence, knowledge, skills, future physical education teachers, educational process.
This paper emphasizes that the improvement of state standards in the field of education is one of the key areas of reforming the system of training future physical education teachers, as the pedagogical activity of a specialist who shapes the child's personality is somewhat difficult. It is determined that the preparation of a student as a future physical education teacher is impossible without self-awareness as a subject of pedagogical activity, which should include the acquisition of special knowledge, skills and abilities and the formation of professional competencies in accordance with the requirements of modern secondary education institutions. The experience of professional training of future physical education teachers, which is carried out in the process of studying psychological-pedagogical, medical-biological and special disciplines, is generalized. It is established that one of the priorities of professional training of future physical education teachers facing the modern system of higher pedagogical education is the effective search and use of optimal ways to improve the effectiveness of educational technologies aimed at forming professional competencies of future teachers. It is proved that the formation of professional competence in institutions of higher education of pedagogical profile should be given great importance. Future physical education teachers must be able to solve complex tasks and problems in the field of physical culture, guided by the principles of tolerant communication, creative and innovative professional activities in workplace situations, characterized by uncertainty of conditions and requirements of today. The structure of the personality of a physical education teacher is substantiated, in which general and professional (subject) competencies, as well as program learning outcomes (knowledge), skills and communication are proved. Emphasis is placed on mastering the system of practical skills and abilities to engage in the main types and forms of rational physical culture activities in secondary education institutions; preservation and strengthening of health, development and improvement of psychophysical capabilities, qualities and personality traits; gaining experience in the creative use of physical culture, health and mass sport activities to achieve personal and professional goals; formation of general culture, humanistic orientation, competence, pedagogical abilities and pedagogical technique; ability to communicate with colleagues, students and their parents.
Постановка проблеми. Пріоритетним завданням сучасної системи освіти є виховання в дусі відповідального ставлення до власного здоров'я і здоров'я оточуючих як до найвищої індивідуальної й суспільної цінності. Провідна роль у цій справі належить учителю фізичної культури. Він повинен уміти створювати такі освітньо-виховні умови, де кожен учень зміг би набути необхідні науково обгрунтовані знання про здоров'я і засоби його зміцнення, шляхи та методики протидії хворобам, способи досягнення високої працездатності й тривалої творчої активності. 
Особливості сучасного стану розвитку освіти зумовлюють необхідність докорінного поліпшення підготовки майбутніх фахівців фізичної культури, яким повинні бути притаманні такі якості: педагогічна спрямованість; професійна компетентність; гармонія розвиненого інтелекту; висока мораль та естетична зрілість; науковий потенціал; постійне самовдосконалення [7, с. 5].

Безумовно, приєднання України до європейського освітнього простору ще більше загострює суперечності у нинішній системі професійної педагогічної освіти, зокрема між метою формування кваліфікованого фахівця і засобами досягнення цієї мети; між завданням забезпечення професійно-особистісного розвитку майбутнього педагога на засадах гуманістичної педагогіки i директивними способами його підготовки; між масовим характером підготовки учительських кадрів та індивідуальним характером педагогічної діяльності кожного вчителя тощо. Отже, не викликає сумнівів необхідність визначення довгострокових стратегій щодо подальшого вдосконалення та розвитку педагогічної освіти, зокрема на рівні професійної підготовки майбутніх учителів у педагогічному університеті [8, с. 87].

Нова концепція розвитку фізичної культури України зумовлює необхідність відповідних змін у підготовці майбутніх учителів фізичної культури. В останні роки помітно зріс інтерес до вивчення ролі і місця фізичної культури в системі вищої освіти, переглядаються сформовані раніше підходи. Це знаходить висвітлення у змісті освітнього стандарту, нових планах і програмах, пошуку шляхів удосконалення професійної підготовки майбутніх учительських кадрів.

Професійна підготовка майбутнього учителя фізичної культури у вищій педагогічній школі являє собою процес становлення його особистості, розвитку загальної і професійної педагогічної культури, компетентності, професійних компетенцій, що виступають передумовою ефективної майбутньої професійної діяльності вчителя в закладах середньої освіти. Професійна готовність майбутнього учителя фізичної культури виступає як цілісний стан особистості, що виражає якісні характеристики її спрямованості, свідомості, професійної позиції, іміджу, рівня оволодіння професійно-педагогічними діями.

Сучасна система підготовки майбутніх учителів фізичної культури має низку недоліків, а реальні результати навчання студентів не завжди відповідають новим вимогам. Причиною такого становища $€$ те, що не вирішуються такі завдання, як прищеплення студентам умінь щодо використання нестандартного обладнання на уроках фізичної культури для підвищення освітньої та виховної спрямованості заняття, збільшення моторної щільності заняття тощо $[2 ; 5]$.
На тлі останніх подій, що відбуваються в Україні, сталися зміни й у системі освіти, у тому числі вищої професійної фізкультурної освіти. До закладів вищої освіти висуваються нові вимоги 3 підготовки майбутніх учителів фізичної культури, які повинні бути конкурентоспроможними, творчими, комунікативними особистостями 3 урахуванням кон'юнктури ринку праці XXI ст. Фізкультурна освіта змінюється в напрямі гуманістичної парадигми та детермінує новий зміст професійної підготовки вчителя фізичної культури на засадах співробітництва, взаєморозуміння, діалогу та педагогічної взаємодії. Функціонування системи вищої освіти можливе лише за умови ефективної педагогічної взаємодії, де два учасники виступають як рівноправні $[1 ; 6]$.

Сучасні заклади середньої освіти висувають підвищені вимоги до особистості вчителя фізичної культури. Це насамперед стосується його професійних якостей, виховних і організаційних здібностей та психолого-педагогічної готовності до майбутньої професійної діяльності. Особливого значення у цьому аспекті набуває здатність учителя фізичної культури компетентно вирішувати різноманітні професійні ситуації, що виникають у його педагогічній діяльності. Особливим критерієм, який характеризує рівень професійнопедагогічної підготовки майбутнього вчителя фізичної культури, постає його професійна компетентність [3; 4].

Мета статті - визначити та обгрунтувати найбільш важливі професійні компетентності майбутніх учителів фізичної культури в процесі здобуття фахової освіти.

Виклад основного матеріалу дослідження. У педагогічній теорії термін «професійна компетентність» визначається як підтверджене право приналежності до певної професійної групи працівників, визнане 3 боку соціальної системи у цілому представниками не лише конкретної професійної групи, а й інших соціальних і професійних груп. Окрім того, професійна компетентність визначає обсяг компетенцій, певне коло повноважень у сфері професійної діяльності. У більш вузькому розумінні під професійною компетенцією розуміється визначена кількість $і$ якість знань, умінь та навичок, у яких суб'єкт має пізнання, досвід, сукупність котрих відображає соціально-професійний статус і професійну кваліфікацію, а також якісні особистісні, індивідуальні особливості (здатності) або якості, що забезпечують можливість реалізації цієї професійної діяльності [9, с. 384].

Важливо сформувати у вчителя фізичної культури здатність компетентно розв' язувати комплексні завдання, керуючись принципами толерантної комунікації, культурної і міжкультурної взаємодії, 
творчої, креативної й інноваційної професійної діяльності у виробничих ситуаціях, що характеризуються невизначеністю умов і вимог.

Сформовані професійні компетентності вчителя фізичної культури мають велике значення для практичної діяльності фахівця. У структурі особистості вчителя фізичної культури знаходять своє відображення такі компетентності: загальні та фахові (предметні), а також програмні результати навчання (знання), уміння та комунікація.

Загальні компетентності - здатність діяти соціально, відповідально та свідомо, виявляти національну й особистісну гідність, громадянську свідомість та активність, дбати про розвиток i функціонування громадянського суспільства; цінувати та поважати різноманітність та мультикультурність; здійснювати професійну діяльність за принципами толерантності, безоціночності іншої особистості; вирішувати конфліктні ситуації та надавати підтримку в нових, проблемних і кризових ситуаціях; навчатися й опановувати сучасні знання; вдосконалювати і розвивати власний інтелектуальний рівень, самостійно набувати i використовувати нові знання й уміння; генерувати нові ідеї, бути готовим проявляти ініціативу й приймати доцільні та відповідальні рішення у проблемних ситуаціях; діяти в нестандартних ситуаціях і нести соціальну й етичну відповідальність за прийнятті рішення; працювати в колективі; ставити актуальні завдання, спрямовувати свої зусилля на досягнення цілей, умотивовувати всіх суб'єктів соціальної взаємодії на їх розв'язання; володіти навичками самоорганізації та саморегуляції; здатність до пошуку, оброблення та аналізу інформації з різних джерел; володіти практичними способами пошуку наукової і професійної інформації з використанням сучасних комп'ютерних засобів, хмарних технологій, баз даних і знань; спілкуватися державною мовою як усно, так і письмово; досконало володіти всіма стилями і жанрами усного і письмового мовлення.

Спеціальні (фахові, предметні) компетенuіï-здатність планувати та здійснювати освітній процес у закладах середньої освіти з предмету «Фізична культура» в урочній та позаурочній формах занять; організовувати масові фізкультурно-спортивні заходи; впроваджувати передові організаційно-методичні форми фізичного виховання; визначати загальні підходи до вибору необхідної методики застосування фізичних вправ; усвідомлювати особливості використання засобів та методів військово-патріотичного виховання школярів; упроваджувати i застосовувати здоров'язберігаючі технології, визначати їх ефективність; організовувати освітній процес у навчальних закладах із використанням сучасних, науково обгрунтованих, традиційних та іннова- ційних засобів, методів, технологій; використовувати моніторинг як механізм удосконалення діяльності у галузі фізичної культури і спорту; реалізовувати контрольно-оцінну та коригувальну функції у професійній діяльності; організовувати систему контролю над психофізичним, медико-біологічним станом учнів, оцінювати і проводити моніторинг їхнього рівня фізичного розвитку, фізичної підготовленості та індивідуального здоров'я; здатність до професійного самовдосконалення: професійна самоосвіта, особистісне зростання, проєктування подальших особистих освітньо-професійних траєкторій.

Програмні результати навчання (знання) знати основні принципи державної політики України у сфері освіти, фізичної культури і спорту та національно-патріотичного виховання школярів; професійні вимоги та обов'язки, соціальні завдання, норми і суспільні цінності; алгоритми ефективної взаємодії з усіма учасниками освітнього процесу, сутність і функції професійної етики; механізми самоорганізації, методи саморегуляції поведінки під час взаємодії з колегами, учнями, батьками; сучасні концепції, завдання, зміст, методи, організаційні форми і засоби, принципи фізичного виховання та основ здоров'я; особливості та інструментарій психолого-педагогічного супроводу освітнього процесу; методи діагностики та корекції психофізичного розвитку особистості; передумови й умови, функції, принципи, мету, завдання, зміст, методи, форми, види моніторингової діяльності спеціаліста 3 фізичної культури й спорту; організаційну структуру i завдання спортивно-масової та фізкультурно-оздоровчої роботи позашкільних навчальних закладів; посадові обов'язки і загальну характеристику основних напрямів діяльності вчителя фізичної культури, організатора спортивно-масової роботи; визначати рівень власної підготовки до професійної діяльності, критично оцінювати, планувати і реалізовувати індивідуальні програми самоосвіти.

Уміння - володіти уміннями і навичками забезпечення організації освітнього процесу з фізичного виховання; виявляти уміння і навички виконання професійної діяльності вчителя фізичної культури, організатора спортивно-масової роботи, керівника гуртка за напрямом підготовки; здійснювати організаційну, методичну, освітню, проєктувальну, контролюючу, фінансово-господарську та інші види робіт, контроль за психофізичним, медико-біологічним станом учнів; оцінювати i проводити моніторинг рівня фізичного розвитку, фізичної підготовленості та індивідуального здоров'я вихованців; використовувати сучасні методи діагностики індивідуального здоров'я; здійснювати моніторинг запитів населення щодо послуг у галузі фізичної культури і спорту, проводити інди- 
відуальну роботу щодо розподілу дітей до занять фізичною культурою і спортом; використовувати широкий спектр форм, засобів, методів самоосвіти і самовдосконалення; проєктувати подальше особистісне зростання, володіти технологіями самовдосконалення.

Комунікація-володіти прийомами спілкування та вміти використовувати їх як у роботі з колективом, так й індивідуально 3 кожним учнем; відчувати потребу в систематичному підвищенні власного загальнокультурного і професійного рівня; використовувати комунікацію для задоволення потреби самовдосконалення та інтелектуального і культурного розвитку; здійснювати взаємодію 3 усіма учасниками освітньо-виховного процесу 3 використанням сучасних інформаційно-комунікаційних технологій; здійснювати пошук науково-практичної інформації, використовувати іiі в освітній та науково-дослідній роботі.
Висновки. Отже, підготовка студента як майбутнього вчителя фізичної культури неможлива без усвідомлення себе як суб'єкта педагогічної діяльності, яка повинна включати в себе як набуття спеціальних знань, умінь та навичок, так і виховання морально-етичного відношення до вибраної професії. Одним зі складників цього процесу $\epsilon$ професійно-особистісна підготовка випускника вищого закладу освіти педагогічного профілю, що забезпечить якісне виконання обов'язків учителя фізичної культури. Провідне місце у цьому напрямі повинно бути відведено фаховій освіті, спрямованій на формування професійних компетентностей до здійснення майбутньої педагогічної діяльності.

Перспектива подальших розвідок у даному напрямі полягає у дослідженні активізації процесу самовиховання майбутніх учителів фізичної культури.

\section{ЛІТЕРАТУРА}

1. Дручик В.Д. Підготовка майбутніх учителів фізичної культури до впровадження здоров'язбережувальних технологій у старшій школі : автореф. дис. ... канд. пед. наук : 13.00 .04 ; Нац. пед. ун-т ім. М.П. Драгоманова. Київ, 2017. 20 с.

2. Євстігнєєва I.В., Захаріна Є.А. Формування вмінь використання нестандартного обладнання на уроках фізичної культури у майбутніх фахівців із фізичного виховання. Науковий часопис Національного педагогічного університету імені М.П. Драгоманова. 2019. Вип. 3 К (110)19. С. 194-197.

3. Каплінський В.В., Асаулюк І.О. Основи виховної діяльності вчителя фізичної культури : навчальний посібник. Київ : КНТ, 2017. 294 с.

4. Карпюк Р.П. Підготовка вчителя фізичної культури до розв'язання професійних ситуацій : автореф. дис. ... канд. пед. наук : 13.00.04 ; Терноп. держ. пед. ун-т ім. В. Гнатюка. Тернопіль, 2004. 20 с.

5. Курдюков Б.Ф. Теория и методология модернизации процесса профессиональной подготовки специалистов физической культуры в системе высшего образования : дис. ... д-ра пед. наук : 13.00 .08 ; Кубанский гос. ун-т физ. культ. спорта и туризма. Краснодар, 2004. 303 с.

6. Митяненко Ю.В. Теоретичні основи формування готовності майбутніх учителів фізичної культури до педагогічної взаємодії у фізкультурно-оздоровчій діяльності. Науковий часопис Національного педагогічного університету імені М.П. Драгоманова. 2019. Вип. 3 К (110)19. С. 365-368.

7. Педагогічна майстерність учителя фізичної культури : навчальний посібник / Г.В. Презлята та ін. Івано-Франківськ : «ЦСТПРІ «ІНІН» ВОI «СОІУ», 2011. 314 с.

8. Радул В.В., Кравцов В.О. Методологічні основи професійного становлення особистості вчителя : навчальний посібник. Кіровоград : Александрова М.В., 2011. 264 с.

9. Сохань Л.В., Срмакова І.І., Нессен Г.М. Життєва компетентність особистості : науково-методичний посібник. Київ : Богдана, 2003. 520 с.

\section{REFERENCES}

1. Druchyk V.D. (2017). Pidhotovka maibutnikh uchyteliv fizychnoi kultury do vprovadzhennia zdoroviazberezhuvalnykh tekhnolohii u starshii shkoli [Prerarationof future physical education teacherstothe implementation of health-saving technologiesin high school]: avtoref. dys. ... kand. ped. nauk : 13.00.04. Nats. ped. un-t im. M.P. Drahomanova. Kyiv.

2. Yevstihnieieva I.V., Zakharina Ye.A. (2019). Formuvannia vmin vykorystannia nestandartnoho obladnannia na urokakh fizychnoi kulturyu maibutnikh fakhivtsiv $\mathrm{z}$ fizychnoho vykhovannia [Formation of skills of using non-standard equipment in physical education lessons for future specialists in physical education]. Naukovyi chasopys Natsionalnoho pedahohichnoho universytetu imeni M.P. Drahomanova : zb. nauk. prats - Scientific journal of National Pedagogical Dragomanov University: Collectionof scientific works, 3 K (110)19, P. 194-197.

3. Kaplinskyi V.V., Asauliuk I.O. (2017). Osnovy vykhovnoi diialnosti vchytelia fizychnoi kultury : navch. posib. [Fundamentals of educational activities of physical education teachers : A Manual]. Kyiv : KNT. 
4. Karpiuk R.P. (2004). Pidhotovka vchytelia fizychnoi kultury do rozviazannia profesiinykh sytuatsii [Preparation of a physical education teacher for solving professional situations]: avtoref. dys. kand. ped. nauk : 13.00.04. Ternop. derzh. ped. un-tim. V. Hnatiuka. Ternopil.

5. Kurdjukov B.F. (2004). Teorija I metodologija modernizacii processa professional'noj podgotovki specialistov fizicheskoj kul'tury $\mathrm{v}$ sisteme vysshego obrazovanija [Theory and methodology of modernization of the process of specialists' professional training in the field of physical culture in the system of higher education]: dis. ... d-raped. nauk : 13.00.08. Kubanskijgos. un-t fiz. kul't. sporta I turizma. Krasnodar.

6. Mytianenko Yu.V. (2019). Teoretychni osnovy formuvannia hotovnosti maibutnikh uchyteliv fizychnoi kultury do pedahohichnoi vzaiemodii u fizkulturno-ozdorovchii diialnosti [Theoretical bases of forming the readiness of future teachers of physical culture for pedagogical interaction in physical culture and recreation activity]. Naukovyi chasopys Natsionalnoho pedahohichnoho universytetu imeni M.P. Drahomanova : zb. nauk. prats - Scientific journal of National Pedagogical Dragomanov University: Collectionof scientific works, 3 K (110)19, P. 365-368.

7. Pedahohichna maisternist uchytelia fizychnoi kultury : navch. posib. [Pedagogical skills of physical education teacher: A Manual] (2011). / H.V. Prezliata ta in. Ivano-Frankivsk : «TsSTPRI «ININ» VOI «SOIU».

8. Radul V.V., Kravtsov V.O. (2011). Metodolohichni osnovy profesiinoho stanovlennia osobystosti vchytelia : navch. posib [Methodological bases of professional formation of the teacher's personality: A Manual]. Kirovohrad : FO-P Aleksandrova M. V.

9. Sokhan L.V., Yermakova I.I., Nessen H.M. (2003). Zhyttieva kompetentnist osobystosti : nauk.-metod. posib. [Life competence of the individual: Scientific and Methodical Manual]. Kyiv : Bohdana. 